\title{
Blåreseptordningen disfavoriserer osteoporosepasienter
}

\author{
Ordningen med legemidler på blå resept er et stort gode for pasienter med kronisk sykdom, men den funge- \\ rer forskjellig for ulike pasientgrupper. Terskelen for å godkjenne et medikament for blåreseptlisten varierer \\ fra sykdom til sykdom.
}

Ordningen med legemidler på blå resept er et stort gode for mange pasienter med kroniske lidelser, men den fungerer forskjellig for ulike pasientgrupper. En årsak er at terskelen for å godkjenne et medikament for blåreseptlisten, varierer fra sykdom til sykdom. Tre eksempler viser dette.

\section{«Hvorfor har blåresept- utvalget slik ulikhet i vurderingen av medikamentelle tiltak for ulike sykdommer?»}

Nye antihypertensiver har kommet inn på listen uten at man med sikkerhet har kunnet påvise effektforbedringer i forhold til konvensjonell behandling (1). En rekke nye medikamenter for type 2-diabetes som alle mangler dokumentasjon for effekt på klinisk relevante endepunkter (mikro- eller makrovaskulære endepunkter) $(2,3)$, har kommet inn på listen. Disse medisinene er mer kostbare enn de «gamle» medikamentene. Dette betyr ikke nødvendigvis at de nye medikamentene er tatt inn på blåreseptlisten på et feilaktig grunnlag, men at blåreseptutvalget i Statens legemiddelverk må ha benyttet liberale kriterier for sine avgjørelser.

Dette står i kontrast til osteoporosebehandling. Osteoporosemedikamenter er undersøkt med definerte endepunkter: vertebrale frakturer, ikke-vertebrale frakturer og hoftefrakturer. Minimumskravet for markedsføringstillatelse er reduksjon $i$ risiko for vertebrale frakturer hos postmenopausale kvinner. Både behandling med parathyreoideahormon, raloxifen, bisfosfonater og denosumab, som har ulike egenskaper og virkningsmekanismer, tilfredsstiller dette kravet (4, 5-7). Flere bisfosfonater og denosumab har også vist at de reduserer risiko for ikke-vertebrale frakturer og hoftebrudd - sistnevnte med $40-50 \%$. Hoftebrudd har en mortalitet på $15-20 \%$, og om lag $50 \%$ av de overlevende har behov for hjelpetiltak, inkludert sykehjemsplass, etter bruddet (8). Når effektiv osteoporosebehandling også reduserer forekomsten av hoftefrakturer (9) og mortalitet på populasjonsnivå (10) og behandling i tillegg er kostnadseffektiv og til og med kostnadsbesparende $(11,12)$, forbauses man over de restriksjoner blåreseptordningen legger på osteoporosebehandling. Hvilket fremskritt hadde det ikke vært om et diabetesmedikament reduserte risiko for hjerteinfarkt med $40-50 \%$ ? Hjerteinfarkt har om lag samme mortalitet som hoftefrakturer både i akutt fase og etter ett år (13).

Hvorfor har blåreseptutvalget slik ulikhet i vurderingen av medikamentelle tiltak for ulike sykdommer? Naturligvis kan man skylde på historisk betinget kutyme, pressgrupper og trange budsjetter, men de siste 15 års økende kunnskap om effekten av medikamentell behandling ved de tre nevnte folkesykdommene synes å ha hatt liten effekt på blåreseptutvalgets praksis. Det er god grunn for utvalget til å utvide både indikasjonsområdene og antall medikamenter på blåreseptlisten for osteoporosebehandling.

\section{Johan Halse \\ johalse@online.no \\ Osteoporoseklinikken \\ Oslo}

Johan Halse (f. 1944) er dr.med. og spesialist i endokrinologi og indremedisin. Han er leder for Osteoporoseklinikken og veileder for doktorander. Oppgitte interessekonflikter: Har mottatt konsulenthonorar fra Amgen, MSD og Novartis, foredragshonorar fra Amgen, SanofiAventis, Eli Lilly, GSK, MSD, Novartis, Novo Nordisk, Nycomed og Roch samt bidrag til kongressdeltakelse fra Amgen, MSD, Novartis og Nycomed.
Litteratur

1. Wright JM, Musini VM. First-line drugs for hypertension. Cochrane Database Syst Rev 2009; nr. 3: CD001841.

2. Ismail-Beigi F, Craven T, Banerji MA et al. Effect of intensive treatment of hyperglycemia on microvascular outcomes in type 2 diabetes: an analysis of the ACCORD randomized trial. Lancet 2010; 376 419-30.

3. Zoungas S, Patel A. Cardiovascular outcomes in type 2 diabetes: the impact of preventive therapies. Ann NY Acad Sci 2010; 1212: 29-40.

4. Stevenson M, Jones ML, De Nigris E et al. A systematic review and economic evaluation of alendronate, etidronate, risedronate, raloxifene and teriparatide for the prevention and treatment of postmenopausal osteoporosis. Health Technol Assess 2005; 22: 1-160.

5. Wells GA, Cranney A, Peterson J et al. Alendronate for primary and secondary prevention of osteoporotic fractures in postmenopausal women. Cochrane Database Syst Rev 2008; nr. 1: CD 001155.

6. Black DM, Delmas PD, Eastell R et al. Once-yearly zoledronic acid for treatment of postmenopausal osteoporosis. N Engl J Med 2007; 356: 1809-22.

7. Cummings SR, San Martin J, McClung MR et al. Denosumab for prevention of fractures in postmenopausal women with osteoporosis. N Engl J Med 2009: 361: 756-65.

8. Forsén L, Sogaard AJ, Meyer HE et al. Survival after hip fracture: short- and long-term excess mortality according to age and gender. Osteoporos Int 1999: 10: 73-8.

9. Siris E, Pasquale MK, Wang Y et al. Estimating bisphosphates use and fracture reduction among US women aged 45 years and older, 2001-2008. J Bone Miner Res 2011; 26: 3-11.

10. Bolland MJ, Grey AB, Gamble GD et al. Effect of osteoporosis treatment on mortality: a metaanalysis. J Clin Endocrinol Metab 2010; 95 : $1174-81$.

11. Johnell O, Jönsson B, Jönsson $L$ et al. Cost effectiveness of alendronate (Fosamax) for the treatment of osteoporosis and prevention of fractures. Pharmacoeconomics 2003; 21: 305-14.

12. Borgström F, Johnell O, Jönsson B et al. Cost effectiveness of alendronate for the treatment of male osteoporosis in Sweden. Bone 2004; 34: $1064-71$.

13. D'Ascenzo F, Gonella A, Quadri G et al. Comparison of mortality rates in women versus men presenting with ST-segment elevation myocardial infarction. Am J Cardiol 2011; 107: 651-4.

Mottatt 10.2. 2011, første revisjon innsendt 14.3. 2011, godkjent 10.4. 2011. Medisinsk redaktør Petter Gjersvik. 